\title{
The relationship between the growth of exports and growth of gross domestic product of India
}

\author{
Mukherji Ronit ${ }^{1}$, Pandey Divya ${ }^{2}$ \\ ${ }^{1}$ M.Sc Economics, University Of Warwick, Coventry, United Kingdom \\ ${ }^{2}$ M.Sc Economics and International Financial Economics, University of Warwick, Coventry, United Kingdom
}

Email address:

ronit.mukherji1992@gmail.com (R. Mukherji),divyapandey4191@gmail.com (D. Pandey)

\section{To cite this article:}

Mukherji Ronit, Pandey Divya. The Relationship between the Growth of Exports and Growth of Gross Domestic Product of India. International Journal of Business and Economics Research. Vol. 3, No. 3, 2014, pp. 135-139. doi: 10.11648/j.ijber.20140303.13

\begin{abstract}
Does Economic Growth Promote Exports of a country or do exports lead to a higher growth? This paper tries to answer this question in the context of India, using a three step procedure of first conducting a Vector Auto Regression (VAR) analysis followed by a Granger Causality Test and an Impulse Response Function. Taking yearly data from 19692012, we find that growth of exports depends positively on growth of GDP with a year lag. Robustness checks show consistent VAR Results. Further the Granger Causality Test determines that GDP Growth causes Export growth in India. Finally Impulse Response Functions generated show that there are much higher responses of export through a change in GDP. So unanimously we find that India backs the theory of Growth Led Exports.
\end{abstract}

Keywords: Exports of India, Growth Led Exports, Vector Auto Regression, Granger Causality, Impulse Response Functions

\section{Introduction}

Most nations today focus on improving their quality of living through increases in their Gross Domestic Product (GDP). Increases in GDP reflect economic growth of a nation. Many researchers have attempted to answer whether export promotion leads to higher economic growth or economic growth promotes exports. The proponents of the export-led growth hypothesis believe that export promotion through export subsidies and devaluation leads to economic growth. Others contradict this by saying that higher economic growth leads to a higher growth in exports. According to them higher growth rate leads to increased productivity which in turn causes growth in exports. Therefore, many developing nations face the dilemma of whether they should open up their economies through export promotion or they should focus on activities within the nation that promote economic growth as a result of which international trade will grow.

The advocates of the export led hypothesis believe that trade was the main engine of growth in South East Asia. According to them the 'Four Tigers', Hong Kong, Taiwan, Singapore and South Korea are enjoying high sustained growth rates because of their free market-oriented economies (World Bank, 1993). Many researchers have investigated the export led hypothesis for developing economies. In his paper, Narayan Chandra Pradhan (2010) states that most of the earlier research works on the nexus between exports and economic growth using crosssectional analysis supported the view of export led growth. However, recent time series analyses using cointegration methodology support the opposite view. Most of the earlier studies could not establish a very consistent causal pattern between exports and output growth.

Before 1991, India was not an open economy. There were several restrictions on international trade. In this year the country faced a balance of payments crisis as a result of which a number of economic reforms were introduced to liberalize the economy. Several economists believe that the high growth rates that India has been enjoying are a result of increase in international trade. High exports enabled the economy to access international markets and better technology which in turn enhanced the growth rate.

This paper is an attempt to investigate the causal relationship between exports and economic growth of India from the period 1969 to 2012 using time series econometric techniques of Vector Auto regression (VAR), Granger Causality test and Impulse Response Function. This study also proves the stationarity of the time series variables used. The Granger Causality test addresses the question of export led growth in India. The Impulse Response Function 
addresses how shocks in one variable affect the other.

\section{Literature Review}

The importance of exports as a driver of economic growth has been a subject of debate. A considerable amount of literature is available on the investigation of the export led growth hypothesis in various countries. The relationship between the two variables has been verified by several studies, however the debate persists. Kaldor (1967) and Krugman (1984) established a one-way causality from output to export. They stated that output growth leads to increased productivity which leads to a higher growth in exports. Marin (1992), through his analysis demonstrates that an "outward-looking" regime enhances the productivity of developed nations which in turn leads to higher economic growth. A study by Kristjanpoller and Olsonon (2014) on Latin American countries proves that a higher growth in exports lead to a higher growth in GDP of these nations.

Most of the studies on India have failed to establish causality between exports and GDP in both directions. Nain's and Ahmad's (2010) study substantiates the validity of the growth-led exports hypothesis in the Indian context. P.K. Mishra's (2011) analysis also proves that causality runs from growth in GDP to growth in exports. He analyzed time series data available on exports and GDP between the periods 1970 to 2009 using the techniques of cointegration and vector error correction estimation. His paper provides evidence for the existence of a long run relationship between the two variables and rejects the hypothesis of exports led growth in favor of growth led exports. Narayan Chandra Pradhan (2010) analyzed the same question. However, he found results that were contradictory to Mishra's findings. In his paper he proves the existence of a short-run and a long-run relationship between export growth and GDP growth. He establishes that causality runs from exports growth to GDP growth using the bivariate Granger causality test.

Dhawan and Biswal (1999) also examined the export led growth hypothesis in the Indian context. They considered the relationship between real GDP, real exports and terms of trade between the periods 1961 and 1993. According to them the Johansen's cointegration procedure proves that there is a long-run relationship between the three variables. They find that causality runs from growth in GDP and terms of trade to growth in exports and the export led hypothesis is a short-run phenomenon in the Indian case.

Using annual data during the period 1950-1992, Mallick (1996) finds a very strong cointegration between income and exports growth in India. Engle-Granger cointegration procedure and the vector error correction model provide evidence that proves that the direction of causality is from growth in income to growth in exports.

An insignificant yet positive F-statistic from income growth to exports growth and vice versa was found by Jung and Marshall (1985) and Dodaro (1993). They found no causality in both directions between exports and income growth. Nidugala (2001) finds that the export led hypothesis holds in the Indian case especially in the 1980s. His study proves that the growth of industrial products significantly affected the growth of income. However there was no influence of exports of primary agricultural products on the growth of income.

It is very clear from the empirical literature available that the exports growth does not necessarily cause a growth in income. Results vary with the applied econometric technique. The cross-sectional analysis mostly proves that there is no causal relationship between the two variables. However, most of the time series analyses either find evidence in favor of the export led hypothesis in India or against it.

\section{Data and Methodology}

\subsection{Data}

The data used has been taken from the database of the Reserve Bank of India which is the country's central bank. The time series annual data set consists of observations on India's exports of goods and services and the real GDP between the periods 1969 and 2012. The real GDP is used as a proxy variable for economic growth in India. The two variables are taken in their natural logarithms to avoid the problem of heteroskedasticity and non stationarity. All econometric exercises have been carried out using Stata. The abbreviations for the data used are as follows:

LNGDP: The natural log of the Gross Domestic Product (GDP at market price at constant prices) of India.

LNEXP: The natural log of the total exports of India.

dLNGDP: The first differencing of LNGDP. This represents the growth in GDP.

dLNEXP: The first differencing of LNEXP. This represents the growth in exports.

The trends and growth rates of the two variables are shown in the graphs below:

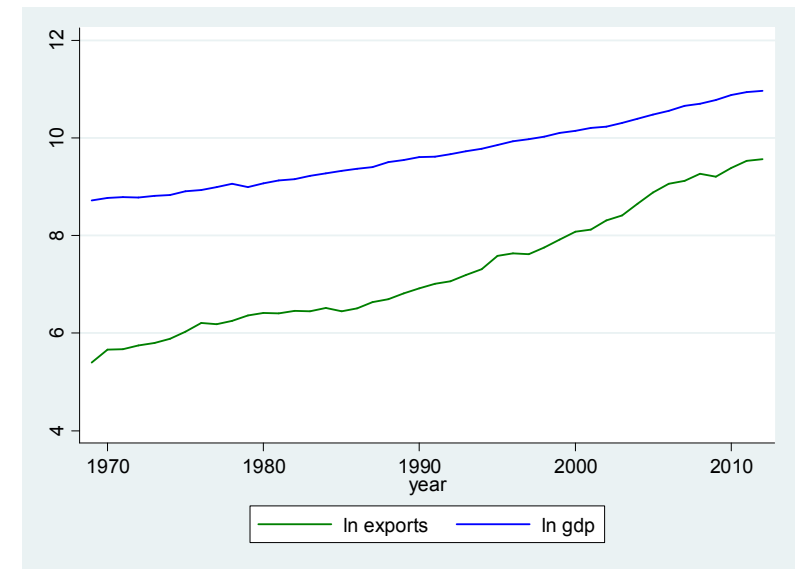

Graph 1. Trend in GDP and Exports of India 


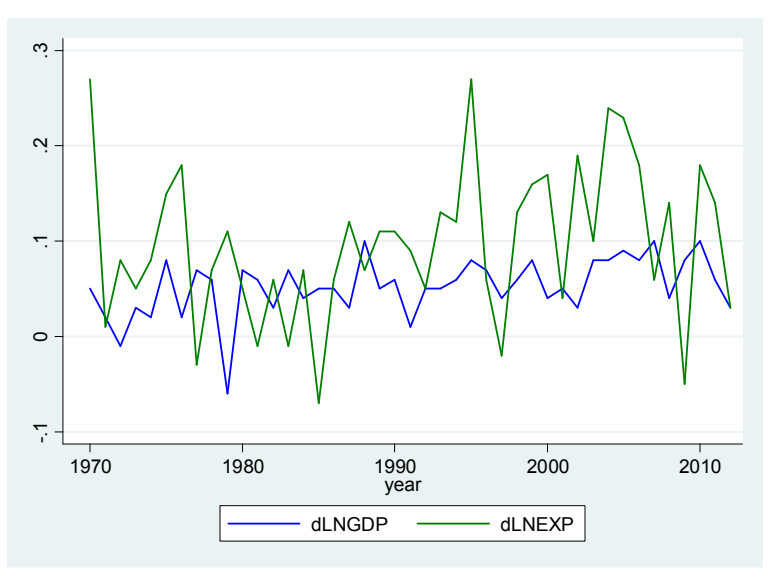

Graph 2. Trends in Growth in GDP and Growth in Exports

The estimation methodology employed in this project consists of four steps:

(i) Unit root test for stationarity of the variables.

(ii) VAR analysis of the two variables during the period 1969-2012.

(iii) Granger causality test.

(iv) Impulse Response Functions

\subsection{Unit Root Test}

In this study the Augmented-Dickey fuller test denoted conventionally as ADF is used to test for the stationarity of the variables. This test consists of running a regression of the first difference of the series on the series lagged once and lagged difference terms. A constant and a time trend may also be included. In this analysis the following expression is used for the ADF test:

$$
\Delta \mathrm{y}_{\mathrm{t}}=\alpha_{0}+\alpha_{1} \mathrm{y}_{\mathrm{t}-1}+\alpha_{2}+\alpha_{\mathrm{j}} \Sigma_{\mathrm{j}} \Delta \mathrm{y}_{\mathrm{t}-\mathrm{j}}+\varepsilon_{\mathrm{t}}, \mathrm{j}=1(1) \mathrm{P}
$$

In this test the null hypothesis is that the series $y_{t}$ is a non-stationary series or it contains a unit root $\left(\mathrm{H}_{0}: \alpha_{1}=0\right)$. The null hypothesis is rejected when the calculated ADF statistic is less than the critical value or when the test statistic is more negative. The rejection of null hypothesis implies that the series is stationary. Failure to reject the null hypothesis leads to conducting the test on the difference of the series. Therefore, further differencing is conducted until stationarity is reached, i.e. the null hypothesis of presence of a unit root is rejected.

Table 1. The results of the ADF Test

\begin{tabular}{|c|c|c|c|}
\hline Series & $\begin{array}{l}\text { ADF } \\
\text { statistic }\end{array}$ & $\begin{array}{l}\text { Critical Values } \\
\text { at } 5 \%\end{array}$ & Decision \\
\hline LNGDP & -1.761 & -3.532 & $\begin{array}{l}\text { Don't reject null } \\
\text { hypothesis }\end{array}$ \\
\hline LNEXP & -1.114 & -3.532 & $\begin{array}{l}\text { Don't reject null } \\
\text { hypothesis }\end{array}$ \\
\hline dLNGDP & -3.961 & -2.955 & Reject null hypothesis \\
\hline dLNEXP & -3.902 & -2.995 & Reject null hypothesis \\
\hline
\end{tabular}

Thus, it can be concluded from the table that the series LNGDP and LNEXP are not trend stationary. However, their first differences dLNGDP and dLNEXP are stationary.
LNGDP and LNEXP follow an I (1) process.

\subsection{VAR Analysis}

"VARs are dynamic systems of equations in which the current level of each variable in the system depends on past movements in that variable and all the other variables in that system". When we are not confident about whether a variable is exogenous or not, then a VAR can be used. A VAR system can be expressed as follows:

$$
\mathrm{Y}_{\mathrm{t}}=\mathrm{A}_{0}+\mathrm{A}_{1} \mathrm{Y}_{\mathrm{t}-1}+\mathrm{A}_{2} \mathrm{Y}_{\mathrm{t}-2}+\ldots . .+\mathrm{A}_{\mathrm{p}} \mathrm{Y}_{\mathrm{t}-\mathrm{p}}+\varepsilon_{\mathrm{t}}
$$

Where $Y_{t}$ is a vector of endogenous variables at time $t, A_{i}$ $(\mathrm{i}=1,2 \ldots \mathrm{p})$ are coefficient vectors, $\mathrm{p}$ is the number of lags included in the system, and $\varepsilon_{\mathrm{t}}$ is a vector of residuals. $\mathrm{A}_{0}$ is a vector of intercept terms.

In this model, the two endogenous variables that will be used are the first difference of the natural logs of exports and GDP denoted by dLNEXP and dLNGDP respectively. Therefore, the transpose of the vector of endogenous variables is given by:

$$
\mathrm{Y}_{\mathrm{t}}=\left[\mathrm{dLNGDP}_{\mathrm{t}} \mathrm{dLNEXP}_{\mathrm{t}}\right]^{\mathrm{T}}
$$

The number of lags taken in this system is two. Hence,

$$
\begin{gathered}
\mathrm{Y}_{\mathrm{t}-1}=\left[\mathrm{dLNGDP}_{\mathrm{t}-1} \mathrm{dLNEXP}_{\mathrm{t}-1}\right]^{\mathbf{T}} \text { and } \mathrm{Y}_{\mathrm{t}-2}=\mathrm{dLNGDP}_{\mathrm{t}-2} \\
\left.\mathrm{dLNEXP}_{\mathrm{t}-2}\right]^{\mathbf{T}}
\end{gathered}
$$

Table 2. Results of second-order VAR model

\begin{tabular}{lll}
\hline Variables affecting dLNEXP & Coefficients & p-value \\
\hline First lag of dLNEXP & .1307853 & 0.395 \\
Second lag of dLNEXP & -.0048273 & 0.972 \\
First lag of dLNGDP & .9153142 & $0.012^{*}$ \\
Second lag of dLNGDP & -.4331255 & 0.258 \\
Constant & .0573778 & 0.051 \\
Variables affecting $\Delta$ LNGDP & Coefficients & p-value \\
First lag of dLNEXP & .1206199 & 0.061 \\
Second lag of dLNEXP & .0290855 & 0.615 \\
First lag of dLNGDP & -.0120346 & 0.937 \\
Second lag of dLNGDP & -.0336957 & 0.834 \\
Constant & .0413599 & 0.001 \\
\hline
\end{tabular}

From the above table it is very evident that the growth of exports significantly depends only on the first lag of the growth in GDP. This relationship is positive. This result is significant at $5 \%$ level of significance $(*)$. The growth of exports also depends positively on the previous year's growth rate but negatively on its second lag and the second lag of growth in GDP. However, these results are insignificant. The growth in GDP is positively dependent on the first and second lags of the growth in exports and negatively dependent on the first and second lags of growth in GDP. These results are also insignificant. Therefore, these results indicate that growth in GDP causes growth in exports in the Indian scenario.

In order to test for autocorrelation in the residuals of the VAR model the LM (Lagrange-Multiplier) test is done. The LM statistic follows chi-square distribution with four degrees of freedom. 


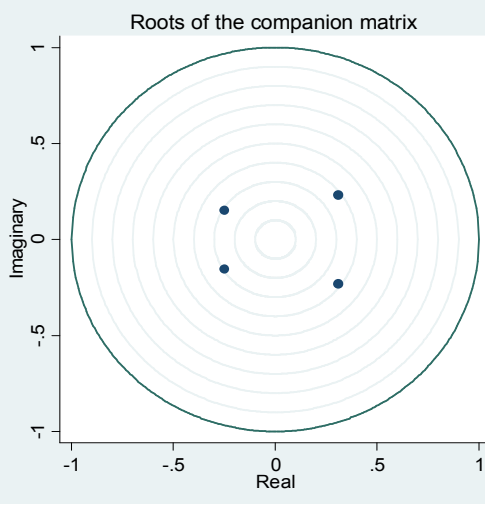

Graph 3. Roots inside Unit Circle

Table 3. Results of LM Test

\begin{tabular}{llll}
\hline Lag & Chi2 & Degrees of freedom & Prob>chi2 \\
\hline 1 & 3.8317 & 4 & 0.42926 \\
2 & 0.4466 & 4 & 0.97849 \\
\hline
\end{tabular}

The results from the LM test prove that there is no autocorrelation in the residuals of the VAR model.

The test for stability of the VAR model is also done. All the Eigen values lie inside the unit circle as shown in the following table and figure below:

Table 4. Results showing Eigen Values

\begin{tabular}{ll}
\hline Eigen values & Modulus \\
\hline $.3087671+.2312457 \mathrm{i}$ & .385761 \\
$.3087671-.2312457 \mathrm{i}$ & .385761 \\
$-.2493917+.1534661 \mathrm{i}$ & .292828 \\
$-.2493917-.1534661 \mathrm{i}$ & .292828 \\
\hline
\end{tabular}

\subsection{Granger Causality Test}

The Granger causality test checks whether the lags of one variable enter in to the equation for another variable. This test refers only to the effects of the past values $\left\{x_{t}\right\}$ on the current values of $x_{t}$. If $\left\{y_{t}\right\}$ does not improve the forecasting performance of $\left\{\mathrm{x}_{\mathrm{t}}\right\}$, then $\left\{\mathrm{y}_{\mathrm{t}}\right\}$ does not Granger cause $\left\{x_{t}\right\}$. The test actually measures whether the current and past values of $\left\{y_{t}\right\}$ help to forecast future values of $\left\{x_{t}\right\}$

The null hypothesis $\left(\mathrm{H}_{0}\right)$ in each case is the variable under consideration does not cause the other variable. The following table depicts the results of the Granger causality Wald test:

Table 5. Granger Test Results

\begin{tabular}{lllll}
\hline Null Hypothesis & Chi-square & Df & Probability & Decision \\
\hline dLNGDP does not cause dLNEXP & 7.6868 & 2 & 0.021 & ${\text { Reject } \mathrm{H}_{0}}^{\prime}$ \\
dLNEXP does not cause dLNGDP & 3.7565 & 2 & 0.153 & ${\text { Don't reject } \mathrm{H}_{0}}$ \\
\hline
\end{tabular}

Table 5 shows that causality runs from GDP growth to exports growth and not vice versa. Therefore, the export led growth hypothesis does not hold in the Indian case. Growth in GDP drives growth in the export sector.

\subsection{Impulse Response Functions}

An impulse response function measures the impact of a unit or one standard deviation shock in the error term associated with variable $\mathrm{j}$ on variable $\mathrm{k}$, some $\mathrm{n}$ periods ahead.

Let $\Delta \mathrm{U}_{\mathrm{j}, \mathrm{t}}=1$, we can write a impulse response function as

$$
\operatorname{IRF}(n, k, j)=E\left[Y_{k, t+n} \mid U_{j, t}=1\right]-E\left[Y_{k, t+n} \mid U_{j, t}=0\right],
$$

Where $Y_{k}$ is a variable and $U_{k}$ is the corresponding error term.

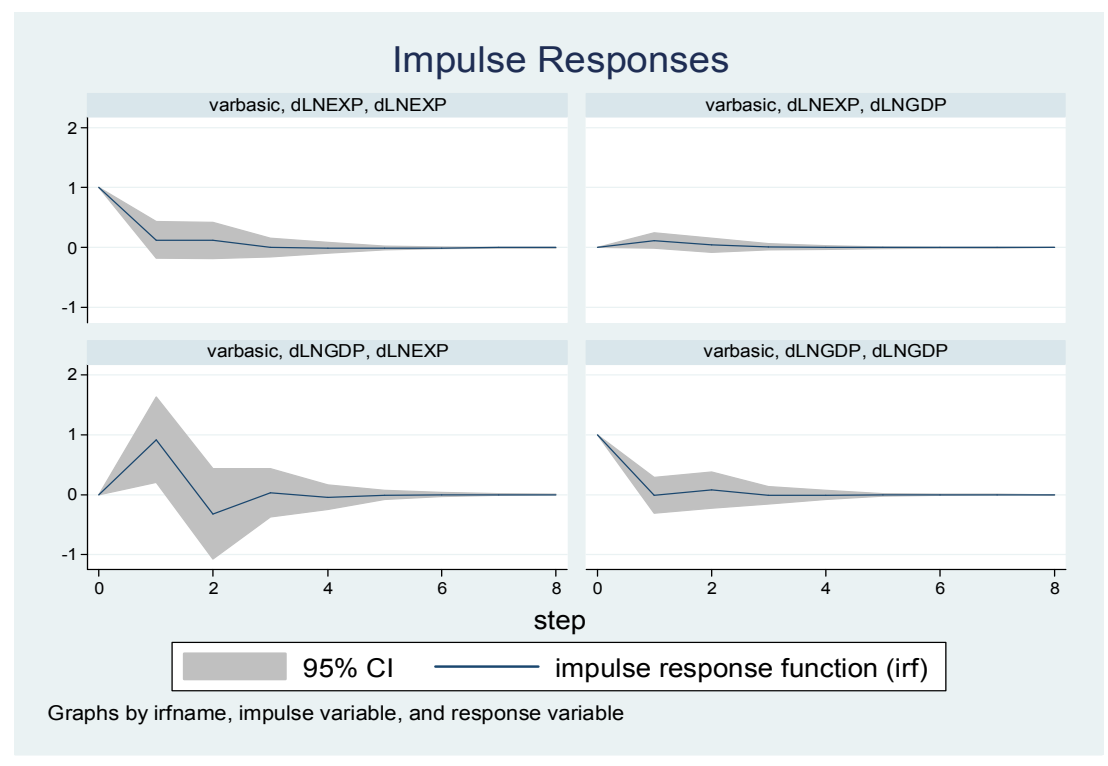

Graph 4. Impulse Response Functions 
In a VAR model the variables are stationary and meanreverting and so the shocks have only a temporary effect on the variables. The graphs of the impulse responses are shown below. They show that if there is a shock to the error term corresponding to the change in log of Gross Domestic Product term then there is a sizeable impact on the variable dLNEXP. So impulses coming from Gross Domestic Product do have an impact on exports whereas the impulses generated from exports do not significantly impact Gross Domestic Product as demonstrated by the graph.

\section{Conclusion}

In this paper the relationship between exports growth and GDP growth has been investigated using VAR analysis, Granger causality test and the Impulse Response Function. The natural logs of the levels of GDP and Exports are nonstationary and their first differences are stationary. Hence, a VAR analysis is done on the growth levels of the two variables.

The stable VAR model shows that the growth in exports of India between the periods 1969 and 2012 depended significantly and positively on the growth of exports. All other results are insignificant. The Granger causality substantiates the fact that the GDP growth in India in not led by growth in exports. In fact, the growth in GDP causes the growth in exports. These results provide evidence against the export led growth hypothesis. The Impulse response Function proves that shocks to growth in GDP affect growth in exports. However, the converse is not true. This further strengthens our finding of growth led exports in the Indian case.

An important reason why growth in the export sector of India does not affect the growth in GDP is that the country has a large domestic market. Exports do not comprise a large part of the GDP. As GDP increases, the demand for goods increases which in turn leads to a rise in the export demand. In other words as the domestic industries grow in size and productivity, the demand for the goods produced by them rises in the international market. Hence, in case of India growth in GDP enhances growth in the export sector. The export led growth hypothesis fails to explain the high growth rates enjoyed by this emerging economy.

\section{References}

[1] Dalia Marin (1992), "Is the Export-Led Growth Hypothesis Valid for Industrialized Countries?" The Review of Economics and Statistics, Vol.74, No. 4 (November, 1992), pp.678-688.
[2] Dhawan, U., and B. Biswal (1999), 'Re-examining Export Led Growth Hypothesis: a Multivariate Cointegration analysis for India', Applied Economics, 31: 525-30.

[3] Dickey, D. A. and W. A. Fuller (1979), 'Distribution of the Estimators for Autoregressive Time Series with a Unit Root', Journal of the American Statistical Association, 74: 427-31.

[4] Dodaro, S. (1993), 'Comparative Advantage, Trade and Growth: Export-Led Growth Revisited', World Development, 19(9): 1153-65.

[5] Granger, C. W. J. (1969), 'Investigating Causal Relations by Econometric Models and Cross-Spectral Methods', Econometrica, 37: 424-38.

[6] Jung, W. S., and P. J. Marshall (1985), 'Exports, Growth and Causality in Developing Countries', Journal of Development Economics, 18: 1-12.

[7] Kaldor N (1967), "Strategic Factors in Economic Development", New York State School of Industrial and Labor Relations, Ithaca, Cornell University, New York.

[8] Krugman P R (1984), "Import Protection as Export Promotion", in H Kierzkowski (Ed.), Monopolistic Competition in International Trade, Oxford University Press, Oxford.

[9] Mallick, S. K. (1996), Causality between exports and economic growth in India: Evidence from Cointegration based Error-Correction Model, Indian Journal of Economics, 76 (302), 307-320.

[10] Mishra, P. K. (2011) : The dynamics of relationship between exports and economic growth in India, International Journal of Economic Sciences and Applied Research, ISSN 17913373, Vol. 4, Iss. 2, pp. 53-70.

[11] Nain, Md. Zulquar ;Ahmad, Wasim, "Export-led Hypothesis in Indian : Some Further Evidences IUP Journal of Monetary Economics, Aug 01, 2010; Vol. 8, No. 3, p. 69-82

[12] Narayan Chandra Pradhan (2010), Reserve Bank of India Occupational papers. Vol. 31, No.3.

[13] Nidugala, G K. (2001), 'Exports and Economic Growth in India: An Empirical Investigation', Indian Economic Journal, 47(3): 67-78.

[14] R, Werner Kristjanpoller; Olson, Josephine E. "Economic Growth in Latin American Countries: Is it Based on ExportLed or Import-Led Growth?" Emerging Markets Finance \& Trade, Jan 02, 2014; Vol. 50, p. 6-20

[15] Walter Enders, Applied Econometric Time Series, $3^{\text {rd }}$ Edition.

[16] Wojciech W. Charemza and Derek F. Deadman, New Directions in Econometric Practice, $2^{\text {nd }}$ Edition. 